\title{
Evaluation of High School Students' Smartphone Addiction and Insomnia Level
}

\author{
Lise Öğrencilerin Akıllı Telefon Bağımlılığı ve Uykusuzluk Düzeyinin \\ Değerlendirilmesi
}

\author{
(1) Özlem Çağan, • Bennur Koca* \\ Eskişehir Osmangazi University Faculty of Health Sciences, Department of Midwifery, Eskişehir, Turkey \\ *Dokuz Eylül University Vocational School of Health Services, PhD RN First and Emergency Aid Program, Izmir, Turkey
}

\begin{abstract}
Objective: To determine the frequency of smartphone addiction among high school students using smart phones and the severity of insomnia. Materials and Methods: This cross-sectional study was performed between April and June 2019 and included high school students. The study group comprised a total of 745 high school students who used smartphones. Their smartphone addiction was analysed using the Smartphone Addiction scale-short form. The Insomnia Severity index was used to evaluate insomnia levels.

Results: According to the findings, 461 (61.9\%) participants were female and $284(38.1 \%)$ were male. The mean age was $15.76 \pm 0.90$ years (range 14-18 years). The frequency of smartphone addiction was found to be $36.9 \%(n=275)$. The important risk factors for smartphone addiction were being a female, checking the smartphone 49 times or more in a day, using the smartphone for $5 \mathrm{~h}$ or more in a day, carrying a charger, spending time on the smartphone before falling asleep at night, checking the smartphone after waking up and having sleep problems. In our study, a weak positive correlation was observed between smartphone addiction and the severity of insomnia.

Conclusion: In this study, smartphone addiction was determined to be an important health problem among high school students. There was a weak positive correlation between smartphone addiction and the severity of insomnia. To reduce smartphone addiction, students, parents and teachers should be informed about the misuse of smartphones.

Keywords: Smartphones, insomnia, high school students
\end{abstract}

Öz

Amaç: Bu çalışmanın amacı, akıllı telefon kullanan lise öğrencileri arasında akıllı telefon bağımlılığı sıklığının saptanması ve uykusuzluk şiddetinin belirlenmesidir.

Gereç ve Yöntem: Bu çalışma, Nisan-Haziran 2019 tarihleri arasında lise öğrencileri üzerinde gerçekleştirilen kesitsel tipte bir araştırmadır. Çalışma kapsamına alınan liselerde öğrenim görmekte olan ve akıllı telefon kullanan toplam 745 öğrenci çalışma grubunu oluşturmuştur. Öğrencilerin akıllı telefon bağımlılığı, Akıllı Telefon Bağımlılığı ölçeği-kısa formu ile değerlendirilmiştir. Uykusuzluk düzeyinin değerlendirilmesi için ise Uykusuzluk Şiddeti indeksi kullanıımışır.

Bulgular: Çalışma grubunu oluşturanların 461'i $(\% 61,9)$ kadın, 284'ü $(\% 38,1)$ ise erkektir. Yaşları 14-18 arasında değişmekte olup, ortalama $15,76 \pm 0,90$ yıl idi. Bu çalışmada akıllı telefon bağımlılığı sıklığı \%36,9 $(n=275)$ olarak saptanmıştır. Akıllı telefon bağımlılığı için önemli risk faktörleri arasında kadın olmak, bir günde akıllı telefonu kontrol etme sayısının 49 kez ve üzerinde olması, bir günde akıllı telefon kullanma süresinin 5 saat ve üzerinde olması, yanında şarj cihazı taşımak, gece uyumadan önce akıllı telefonla zaman geçirilmesi, uyandıktan sonra akıllı telefonun kontrol edilmesi ve uyku sorunu yaşamak olduğu görülmüştür. Çalışmamızda akıllı telefon bağımlıı̆ı ile uykusuzluk şiddeti arasında pozitif yönde zayıf bir ilişki olduğu saptanmıştır.

Sonuç: Bu çalışmada lise öğrencileri arasında akıllı telefon bağımlıı̆ının önemli bir sağlık sorunu olduğu saptanmıştır. Akıllı telefon bağımlıı̆ı ile uykusuzluk şiddeti arasında pozitif yönde zayıf bir ilişki vardır. Akıllı telefon bağımlıı̆ı̆ının azaltılması için akıllı telefonların amaç dışı kullanılmaması konusunda öğrencilere, velilere ve öğretmenlere bilgilendirme çalışmalarının yapılması yararlı olacaktır.

Anahtar Kelimeler: Akıllı telefon, uykusuzluk, lise öğrenci

\section{Introduction}

The use of technology has been increasing rapidly especially among young people in recent years, and it can reshape the lifestyle of children and adolescents (1). Adolescence, which has an important place in the developmental periods of human beings, is a period in which individuals search for identity, they go through emotional changes, and friendship and social environment are important (2). Factors such as emotional 
problems, the need for socialization, and the search for identity can make technology an attractive tool for adolescents. Excessive use of technology that starts with these feelings and thoughts can turn into a problem by adversely affecting the social and psychological world of the individual and leading to undesirable consequences and deterioration in important life areas $(3,4)$. Adolescence is a period when risky behaviors are inevitable and is considered as a critical stage in terms of technological addictions such as internet addiction, social media addiction, digital game addiction, and smartphone addiction. Also, the use of technologies such as the internet, social media, smartphone, and digital games is more common among adolescents. This situation can make adolescents more vulnerable to technology addiction (5).

In adolescence, sleep routine is very important, and poor or inadequate sleep affects growth and development negatively (6). However, sleep disorders are known to increase in schoolage children, and this problem gets even worse with age (7). There is an inverse relationship between sleep time and age (8). In addition to inadequate sleep time, problems related to poor sleep have also increased in adolescents (9). Many factors affect the duration and quality of sleep in adolescents negatively. Among these factors, increased use of smartphones and addiction to these devices particularly stand out. In addition to communication, smartphones are also used for surfing the internet, accessing social networks, taking photos, shopping, sending emails, listening to music, playing games, getting traffic information, and navigation $(10,11)$. These behaviors are shown to cause short and poor night sleep among adolescents who are addicted to mobile phones (12).

This study was carried out to determine the frequency of smartphone addiction among high school students using smartphones and the severity of insomnia, and to analyze some variables that are thought to be associated with the issue.

\section{Materials and Methods}

This study used a cross-sectional research design and was conducted on high school students using smartphones between April and June 2019.

At the outset, approval of Dokuz Eylül University noninterventional Research Ethics Committee with issue 2019/0160 was obtained. To collect the data, necessary permissions were obtained from the District National Education Directorates, related school administrations, students, and parents.

The study group consisted of $9^{\text {th }}, 10^{\text {th }}, 11^{\text {th }}$, and $12^{\text {th }}$-grade students enrolled in Muzaffer Çil Anatolian High School and İzmir İnönü Anatolian High School. There were a total of 1.552 students in these two schools including 600 in Eskişehir Muzaffer Çil Anatolian High School and 952 in İmir Inönü Anatolian High School. In the study, we aimed to reach all of the students, but a total of 745 students who were at school during the study process and agreed to participate in the study made up the study group.

In the study, a questionnaire form was designed in light of the literature. The questionnaire included questions about some socio-demographic characteristics of students, some variables that were thought to be associated with smartphone addiction, and the questions of the Smartphone Addiction scale and the Insomnia Severity index.

The date and time of the interviews for data collection were determined by contacting the school administrators in advance. The researcher went to the schools on the pre-determined days and hours and checked the study group. After explaining the purpose and subject of the study to the students, verbal consent was obtained from those who agreed to participate in the study, and the questionnaire forms were handed out to the students. The students filled out the forms under observation. This process took nearly $15-20$ minutes. Students who were absent during the data collection process or who did not agree to participate in the study were not included in the study.

In this study, students' smartphone addiction was evaluated using the Smartphone Addiction scale-short form. The scale was developed by Kwon et al. (13) in 2013 to measure the risk of smartphone addiction in adolescents. The validity and reliability study of the scale in Turkey was conducted by Noyan et al. (14) in 2015. Cronbach's alpha value of the scale was calculated as 0.867 . The scale consists of ten 6-point Likert-type questions, and the questions are scored from 1 to 6 . The scores that can be obtained from the scale vary between 10 and 60, and high scores are considered to show an increased risk for addiction. Males with a score of 31 or greater and females with a score of 33 or greater are interpreted as "smartphone addicts".

The insomnia levels of the students were analyzed with the Insomnia Severity index. The scale was developed by Bastien et al. (15). The validity and reliability study was conducted by Boysan et al. (16) and Cronbach's alpha value was calculated as 0.79 (16). Each item on the seven-item 5-point Likert-type scale is scored between 0 and 4 , and the total score that can be obtained from the scale varies between 0 and 28. As the score obtained from the scale increases, the severity of insomnia is considered to increase, as well.

In this study, family income status was evaluated as "good", "moderate", and "bad" according to the students' own perceptions.

\section{Research questions are;}

High school students'

1. Are they addicted to smartphone addiction?

2. What are the independent variables (socio-demographic features, smartphone usage features, sleep characteristic) associated with high school students' smartphone addiction?

3. What are the risk factors for smartphone addiction?

\section{Statistical Analysis}

The data obtained were analyzed on the Statistical Software Package. For analyses, chi-square test, Logistic Regression Analysis (Backward Wald), and Spearman's correlation analysis were used. The statistical significance was accepted as $p \leq 0.05$.

\section{Results}

According to the findings, 461 (61.9\%) of the participants were female and $284(38.1 \%)$ were male. The mean age was $15.76 \pm 0.90$ years ranging between 14 and 18 . The frequency 
of smartphone addiction among students was determined as $36.9 \%(n=275)$. Table 1 presents the distribution of the participants with and without smartphone addiction by some socio-demographic characteristics.

The mean length of having a smartphone in the study group was found to be $3.88 \pm 1.75$ years ranging between 1 and 12 years. The mean smartphone use of the students a day was $4.33 \pm 2.62$ ranging between 1 and 17 hours. The mean daily sleep time was $7.49 \pm 1.15$ hours which varied between 4 and 11 hours. The number of participants carrying chargers was 201 $(27.0 \%)$, and the number of those who had sleep problems was 211 (28.3\%). Table 2 gives the distribution of the students diagnosed with or without smartphone addiction by some characteristics considered to be associated with smartphone addiction.

Table 3 gives the results of the logistic regression analysis (backward wald) conducted on variables considered to be associated with smartphone addiction (number of daily smartphone checks, duration of daily smartphone use, carrying a charger, spending time on the smartphone before falling asleep at night, checking the smartphone after waking up, history of sleep problems, and daily sleep time). In our study, the students were found to use the smartphone most frequently for social media with $21.6 \%$ and least frequently for mobile applications with $8.0 \%$. The reasons for smartphone use in the study group are given in Table 4 .

The mean score obtained from the Smartphone Addiction scale was 28.86 \pm 10.94 , which ranged between 10 and 60, and the mean score obtained from the Insomnia Severity index was $7.97 \pm 4.96$, which varied from 0 to 26 . A weak positive correlation was found between the scores that students obtained from the Insomnia Severity index and the scores they obtained from the Smartphone Addiction scale $(r=0.319$, $p=0.000$ ). The distribution of the scores obtained by the study group from the Insomnia Severity index and the Smartphone Addiction scale is shown in Chart 1 and Table 5.

\section{Discussion}

In recent years, there has been an increase in smartphone addiction and insomnia problems among high school students and it has become an important public health problem. In this study, the frequency of smartphone addiction and the severity of insomnia among high school students using smartphones in İzmir and Eskişehir provinces were discussed in line with the literature.

Our study showed that students spent an average of 5 hours or more a day on mobile phones. They were determined to use the smartphone most frequently for social media with $21.6 \%$ and least frequently for mobile applications with $8.0 \%$.

According to the 2018 "ICT usage survey in households" data of the Turkish Statistical Institute, internet use was $59.6 \%$ among individuals aged 16 in Turkey. According to this report, the rate of social media use ranks first among the reasons for internet use (17).

In the present study, smartphone addiction among students was found to be $36.9 \%$. Different results have been found in studies conducted in different countries. For example, in their study on medical students in Eastern Nepal, Thapa et al. (18) found it as 21.8\%; in their study on university students in China, Bian and Leung (19) found the value as 13.6\%; another study on college students in England by Lopez-Fernandez et al. (20) found it as 10.0\%; Smetaniuk (21) determined this value as $25.0 \%$ on college students in America; in their study on adolescents in Switzerland, Haug et al. (22) found it as 16.9\%; Chen et al. (23) determined it as 29.8 in a study on medical students in China; Nowreen found it as $34.4 \%$ in a study on medical students in India.

Table 1. The distribution of the participants with and without smartphone addiction by some socio-demographic characteristics

\begin{tabular}{|c|c|c|c|}
\hline \multirow[b]{2}{*}{ Socio-demographic characteristics } & \multicolumn{2}{|c|}{ Smartphone addiction } & \multirow[b]{2}{*}{$\begin{array}{l}\text { Test value } \\
\chi^{2}, p\end{array}$} \\
\hline & $\begin{array}{l}\text { No } \\
n=470(63.1)\end{array}$ & $\begin{array}{l}\text { Yes } \\
\mathrm{n}=275 \\
(36.9)\end{array}$ & \\
\hline \multicolumn{4}{|l|}{ School } \\
\hline Muzaffer Çil Anatolian high school & $213(45.3)$ & $159(57.8)$ & $11,968,0.003$ \\
\hline \multicolumn{4}{|l|}{ Age groups } \\
\hline$\leq 15$ & $211(44.9)$ & $127(46.1)$ & \multirow{3}{*}{$2.396,0.302$} \\
\hline 16 & $141(30.0)$ & $92(33.5)$ & \\
\hline$\geq 17$ & $118(25.1)$ & $56(20.4)$ & \\
\hline \multicolumn{4}{|l|}{ Gender } \\
\hline Good & $68(14.5)$ & $57(20.7)$ & \multirow{2}{*}{$4.868,0.027$} \\
\hline Moderate-bad & $402(85.5)$ & $218(79.3)$ & \\
\hline
\end{tabular}




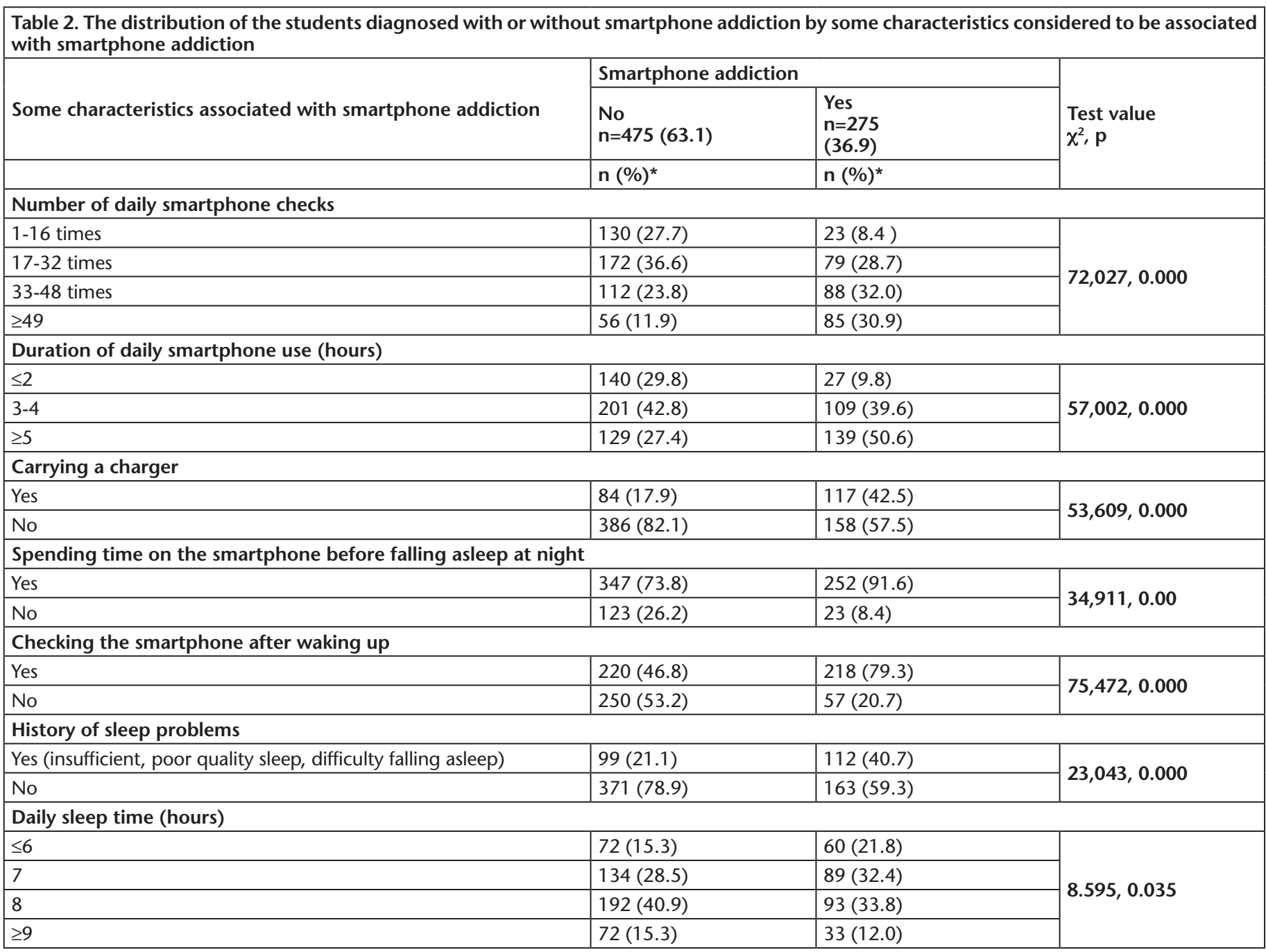

\begin{tabular}{|c|c|c|c|c|c|}
\hline \multicolumn{6}{|c|}{ Number of daily smartphone checks (reference: 1 hour) } \\
\hline 33-48 times & 0.418 & 0.313 & 0.182 & 1.519 & $0.823-2.805$ \\
\hline$\geq 49$ & 0.918 & 0.339 & 0.007 & 2.503 & $1.287-4.868$ \\
\hline$\geq 5$ & 0.963 & 0.287 & 0.001 & 2.621 & $1.492-4.602$ \\
\hline \multicolumn{6}{|c|}{ Carrying a charger } \\
\hline Yes & 0.882 & 0.192 & 0.000 & 2.415 & $1.658-3.518$ \\
\hline \multicolumn{6}{|c|}{ Spending time on the smartphone before falling asleep at night } \\
\hline Yes & 0.634 & 0.277 & 0.022 & 1.886 & 1.096-3.243 \\
\hline Yes & 0.780 & 0.192 & 0.000 & 2.182 & $1.499-3.178$ \\
\hline Constant & -4.100 & 0.427 & 0.000 & - & - \\
\hline
\end{tabular}


Çağan and Koca.

Smartphone Addiction and Insomnia Levels

\begin{tabular}{|l|l|l|}
\hline \multicolumn{2}{|l|}{ Table 4. The reasons of the students in the study group for smartphone use } & Percentage \\
\hline The reasons for smartphone use & Number* & 14.2 \\
\hline Talking & 411 & 20.3 \\
\hline Texting & 588 & 10.0 \\
\hline Playing games & 291 & 21.6 \\
\hline Social media & 627 & 8.0 \\
\hline Mobile applications & 232 & 9.7 \\
\hline Taking photos & 283 & 14.6 \\
\hline Search for information/doing homework & 423 & 1.6 \\
\hline Other & 47 & 100.0 \\
\hline Total & 2.902 & \\
\hline${ }^{*}$ The numbers refer to the number of reasons, not persons & & \\
\hline
\end{tabular}

Table 5. Correlation analysis between insomnia severity index and the smartphone addiction scale

\begin{tabular}{|l|l|l|}
\hline & Smartphone addiction & Insomnia Severity index \\
\hline Smartphone addiction & 1.000 & \\
$\mathrm{p}$ & $\cdot$ & 0.319 \\
\hline $\begin{array}{l}\text { Insomnia Severity index } \\
\mathrm{p}\end{array}$ &. & 0.000 \\
$\mathrm{p}$ & $\cdot$ & 1.000 \\
\hline
\end{tabular}

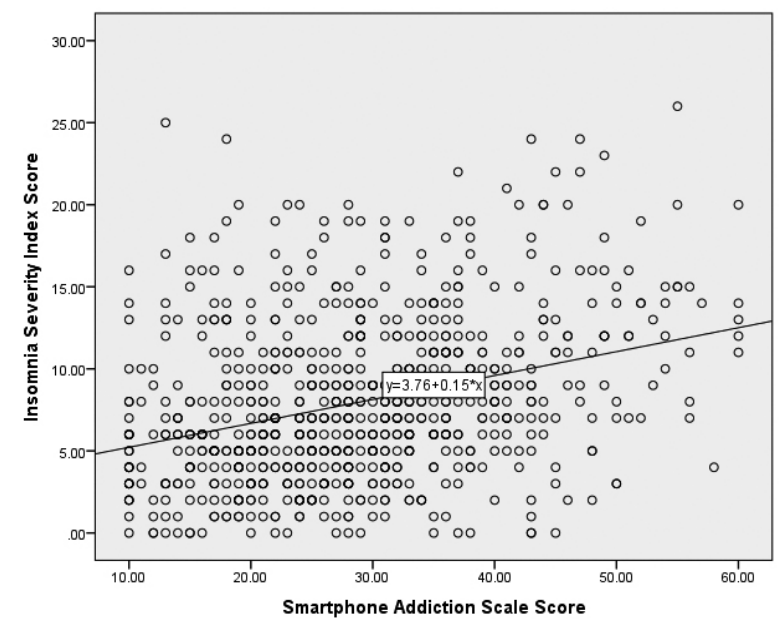

Chart 1. The distribution of the scores obtained by the study group from the Insomnia Severity index and the Smartphone Addiction scale

Smartphone addiction was found higher among Muzaffer Çil Anatolian High School students compared to that of other high school students. However, the result of the logistic regression analysis indicated that there was no difference between schools in terms of smartphone addiction. This may have resulted from the fact that the students enrolled in the study from two different cities had similar socio-economic levels and that the high schools they were attending were similar in terms of the region where they were located, qualifications, and characteristics.
There was no difference between age groups in terms of smartphone addiction, either. This might have been because the age of the students was close to each other.

Smartphone addiction was found to be higher among females than males. As a result of the logistic regression analysis, the difference between males and females was observed to disappear. These findings were consistent with the findings of previous studies on students $(1,11,22)$. This situation can be explained by the acceptance of commitment within the scope of social values for females and the attribution of this commitment to a tool.

The frequency of smartphone addiction was found to be higher among the participants with good family income.

In the study, as the number of daily smartphone checks increased, the frequency of smartphone addiction was determined to increase, as well. As a result of the logistic regression analysis, the frequency of smartphone addiction was observed to be 2.503 times higher in those who checked their smartphone 49 times a day or more. Pavithra and Madhukumar (24) stated in their study that the behavior and habit of checking the screen was one of the characteristic features of mobile phone addiction and smartphone addiction.

Students' frequency of smartphone addiction increased as their daily smartphone screen time increased. As a result of the logistic regression analysis, the duration of daily smartphone use for 5 hours or more was found to be an important risk factor for smartphone addiction.

The frequency of smartphone addiction was found to be higher in students in the study group carrying a charger. The result of the logistic regression analysis indicated that the frequency of smartphone addiction was 2.415 times higher among those 
carrying a charger. In their study, Pavithra and Madhukumar (24) found results similar to the findings of our study. Running out of the battery of the smartphone is a situation that leads to concerns in individuals with smartphone addiction. To avoid this situation, these individuals constantly try to keep their smartphones on and in range. Given that the small size and lightweight body of these devices facilitate their portability today, it is an expected outcome that individuals who are at risk of smartphone addiction carry a charger.

Features related to mobile phone use and smartphone addiction are also important factors related to sleep quality. Some studies in the literature investigate the relationship between smartphone addiction and sleep quality $(11,25)$. The cause-effect relationship between smartphone addiction and sleep quality is not fully known; yet, the following negative consequences are thought to show up: excessive smartphone use result in stimulating effect; exposure to excess stimulants just before falling asleep due to smartphone use leads to difficulty falling asleep and sleep disruptions; the reduction of melatonin hormone release due to the exposure to the smartphone screen light delays the circadian rhythm; curiosity raised due to social media use through smartphone results in sleep disruptions $(26,27)$. In our study, the frequency of smartphone addiction was found to be higher among students whose daily sleep time was less than 6 hours. Also, smartphone addiction was determined to be higher in those who spent time on the smartphone before falling asleep at night, checked smartphone after waking up, and had sleep disorders.

In our study, a weak positive correlation was found between the scores students obtained from the Insomnia Severity index and the Smart Phone Addiction scale. The results were found to support the findings that the students had sleep problems. In a study investigating the relationship between sleep quality and smartphone addiction in university students, Özcan (28) reported that $64.5 \%$ of the students with smartphone addiction had poor sleep quality, but that this rate was $45.9 \%$ in those who did not have the addiction. Similar to our study, a significant positive correlation was found between the Pittsburgh Sleep Quality index total score and Smartphone Addiction scale-short form scores (28). A study in the literature stated that prolonged smartphone use caused sleep disorders and also an increase in conditions such as fatigue and sleep deprivation due to exposure to bright light (29).

\section{Study Limitations}

The use of cross-sectional research design, the small number of schools included in the study, and the lack of objective diagnostic methods were among the limitations of the current study. Another limitation of the study was that some of the informed consent forms sent to parents through students was not handed over to parents or returned to researchers. For this reason, researchers often went to the schools and tried to send the forms to parents through students. This resulted in losses in the sample and extra time and cost for researchers to reach the targeted number of students.

\section{Conclusion}

In this study, smartphone addiction was found to be an important health problem among high school students. Important risk factors for smartphone addiction was observed to include being a female, daily smartphone checks 49 times or more, daily time of smartphone use that is 5 hours or more, carrying a charger, spending time on the smartphone before falling asleep at night, screen checks after waking up, and having sleep problems. The students were found to use the smartphone most frequently for social media and least frequently for mobile applications. In our study, a weak positive correlation was found between smartphone addiction and insomnia severity. Carrying out programs for informing students, parents, and teachers about the misuse of smartphones to reduce smartphone addiction will be beneficial. More comprehensive studies are needed to reveal the relationship between smartphone addiction and insomnia.

\section{Acknowledgements}

We would like to express our gratitude to the teachers who supported us greatly in conducting the study and to the students and their parents who volunteered to participate in the study.

\section{Ethics}

Ethics Committee Approval: At the outset, approval of Dokuz Eylül University Non-interventional Research Ethics Committee with issue 2019/01-60 was obtained.

Informed Consent: The study was that some of the informed consent forms sent to parents through students was not handed over to parents or returned to researchers.

Peer-review: Internally peer-reviewed.

\section{Authorship Contributions}

Concept: Ö.Ç., Design: Ö.Ç., Data Collection or Processing: Ö.Ç., B.K., Analysis or Interpretation: Ö.Ç., B.K., Literature Search: Ö.Ç., Writing: Ö.Ç.

Conflict of Interest: No conflict of interest was declared by the authors.

Financial Disclosure: The authors declared that this study received no financial support.

\section{References}

1. Lee JE, Jang SI, Ju YJ, Kim W, Lee HJ, Park EC. Relationship between mobile phone addiction and the incidence of poor and short sleep among Korean adolescents: a longitudinal Study of the Korean Children \& Youth Panel Survey. J Korean Med Sci 2017;32:1166-72.

2. Johansson A, Götestam G. Internet addiction: Characteristics of a Questionnaire and Prevalence in Norwegian Youth (12-18 Years). Scand J Psychol 2004;45:223-29.

3. Cerniglia L. Zoratto F, Cimino S. Laviola G, Ammaniti M, Adriani W. Internet addiction in adolescences: neurobiological, psychosocial and clinical issues. Neurosci Biobehav Rev 2017;76:174-84.

4. Cerutti R, Presaghi F, Spensieri V, Valastro C, Guidetti V. The potential Impact of Internet and mobile use on headache and other somatic symptoms in adolescence. A population-based cross-sectional study. Headache 2016;56:1161-70. 
5. Park SY, Yang S, Shin CS, Jang H, Park SY. Long-Term Symptoms of Mobile Phone Use on Mobile Phone Addiction and Depression Among Korean Adolescents. Int J Environ Res Public Health 2019;16:3584.

6. Kim JH, Park EC, Lee SG, Yoo KB. Associations between time in bed and suicidal thoughts, plans and attempts in Korean adolescents. BMJ Open 2015;5:e008766.

7. Gradisar M, Gardner G, Dohnt H. Recent worldwide sleep patterns and problems during adolescence: a review and meta-analysis of age, region, and sleep. Sleep Med 2011;12:110-8.

8. Dollman J, Ridley K, Olds T, Lowe E. Trends in the Duration of SchoolDay Sleep Among 10- to 15-year-old South Australians Between 1985 and 2004. Acta Paediatr 2007;96:1011-4.

9. Kronholm E, Puusniekka R, Jokela J, Villberg J, Urrila AS, Paunio T, Välimaa R, Tynjälä J. Trends in self-reported sleep problems, tiredness and related school performance among finnish adolescents from 1984 to 2011. J Sleep Res 2015;24:3-10.

10. Darvishi M, Noori M, Nazer MR, Sheikholeslami S, Karimi E. Investigating different dimensions of nomophobia among medical students: a cross-sectional study. Open Access Maced J Med Sci 2019;7:573-8.

11. Tamura H, Nishida T, Tsuji Aand, Sakakibara H. Association between excessive use of mobile phone and ınsomnia and depression among Japanese adolescents. Int J Environ Res Public Health 2017;14:701.

12. Punamäki RL, Wallenius $M$, Nygård $C H$, Saarni $L$, Rimpelä $A$. Use of Information and communication technology (ICT) and perceived health in adolescence: the role of sleeping habits and waking-time tiredness. J Adolesc 2007; 30:569-85.

13. Kwon M, Kim DJ, Cho H,Yang S. The smartphone addiction scale: development and validation of a short version for adolescents. Plos One 2013;8:1-7.

14. Noyan CO, Enez Darçın A, Nurmedov S, Yılmaz O, Dilbaz N. Akıllı Telefon Bağımlılığı Ölçeğinin Kısa Formunun Üniversite Öğrencilerinde Türkçe Geçerlilik ve Güvenilirlik Çalışması. Anadolu Psikiyatri Derg 2015;16 (Özel sayı 1):73-81.

15. Bastien $\mathrm{CH}$, Vallières $\mathrm{A}$, Morin $\mathrm{CM}$. Validation of the Insomnia severity index as an outcome measure for Insomnia research. Sleep Med 2001;2:297-307.

16. Boysan M, Güleç M, Beşiroğlu L. Uykusuzluk şiddeti indeksinin Türk örneklemindeki psikometrik özellikleri. Anadolu Psikiyatri Derg 2010;11:248-52.

17. Türkiye Istatistik Kurumu (TÜIKK) Hane Halkı Bilişim Teknolojileri Kullanım Araştırması. Available from: http://www.tuik.gov.tr/ PreHaberBultenleri.doid=21779
18. Thapa K, Lama S, Pokharel R, Rambha S, Rimal SP. Mobile phone dependence among undergraduate students of a medical college of Eastern Nepal: a descriptive cross-sectional study. JNMA J Nepal Med Assoc 2020;58:234-9.

19. Bian M, Leung L. linking loneliness, shyness, smartphone addiction symptoms, and patterns of smartphone use to social capital. Soc Sci Comput Rev 2015;33:61-79.

20. Lopez-Fernandez O, Honrubia-Serrano L, Freixa-Blanxart M, Gibson W. Prevalence of problematic mobile phone use in British adolescents. Cyberpsychol Behav Soc Netw 2014;17:91-8.

21. Smetaniuk P. A preliminary investigation into the prevalence and prediction of problematic cell phone use. J Behav Addict 2014;3:41-53.

22. Haug S, Castro RP, Kwon M, Filler A, Kowatsch T, Schaub MP. Smartphone use and smartphone addiction among young people in Switzerland. J Behav Addict 2015;4:299-307.

23. Chen B, Liu F, Ding S, Ying X, Wang L, Wen Y. Gender differences in factors associated with smartphone addiction: a crosssectional study among medical college students. BMC Psychiatry 2017; 17:341.

24. Pavithra MB, Madhukumar SA. Study on nomophobia-mobile phone dependence, among students of a medical college in Bangalore. Natl J Community Med 2015;6:340-4.

25. Mohammadbeigi A, Absari R, Valizadeh F, Saadati M, Sharifimoghadam S, Ahmadi A, Mokhtari M, Ansari H. Sleep quality in medical students; the Impact of over-use of mobile cell-phone and social networks. J Res Health Sci 2016;16:46-50.

26. Nowreen N, Ahad F. Effect of smartphone usage on quality of sleep in medical students. Natl J Physiol Pharm Pharmacol 2018;8:1366-70.

27. Fuller C, Lehman E, Hicks S, Novick MB. Bedtime Use of technology and associated sleep problems in children. Glob Pediatr Health 2017;4:1-8.

28. Özcan B. Pamukkale Üniversitesi öğrencilerinde uyku kalitesi ve akıllı telefon bağımlılığı ile ilişkisi (Uzmanlık Tezi), Pamukkale Üniversitesi Halk Sağlığı Anabilim Dalı, Denizli. 2019;1-84.

29. Moattari M, Moattari F, Kaka G, Kouchesfahani HM, Sadraie SH, Naghdi M. Smartphone addiction, sleep quality and mechanism. Int J Cognition Behav 2017;1:1-7. 